\title{
Optimized PCR with sequence specific primers (PCR-SSP) for fast and efficient determination of Interleukin-6 Promoter ${ }^{-597 /-572 /-174}$ Haplotypes Michael Müller-Steinhardt*, Friederike Schulte, Harald Klüter and Peter Bugert
}

\begin{abstract}
Address: Institute of Transfusion Medicine and Immunology, Medical Faculty Mannheim, Heidelberg University, Friedrich-Ebert-Straße 107, 68167 Mannheim, Germany, DRK-Blutspendedienst Baden-Württemberg - Hessen, Germany

E-mail: Michael Müller-Steinhardt* - m.mueller-steinhardt@blutspende.de; Friederike Schulte - m.mueller-steinhardt@blutspende.de; Harald Klüter - h.klueter@blutspende.de; Peter Bugert - peter.bugert@medma.uni-heidelberg.de ${ }^{*}$ Corresponding author
\end{abstract}

Published: 10 December 2009

BMC Research Notes 2009, 2:245 doi: 10.1186/1756-0500-2-245
Received: 26 June 2009

Accepted: 10 December 2009

This article is available from: http://www.biomedcentral.com/I756-0500/2/245

(C) 2009 Müller-Steinhardt et al; licensee BioMed Central Ltd.

This is an Open Access article distributed under the terms of the Creative Commons Attribution License (http://creativecommons.org/licenses/by/2.0), which permits unrestricted use, distribution, and reproduction in any medium, provided the original work is properly cited.

\begin{abstract}
Background: Interleukin-6 (IL-6) promoter polymorphisms at positions $-597(\mathrm{G} \rightarrow \mathrm{A}),-572$ $(\mathrm{G} \rightarrow \mathrm{C})$ and $-174(\mathrm{G} \rightarrow \mathrm{C})$ were shown to have a clinical impact on different major diseases. At present PCR-SSP protocols for IL-6 ${ }^{-597 /-572 /-174}$ haplotyping are elaborate and require large amounts of genomic DNA.

Findings: We describe an improved typing technique requiring a decreased number of PCRreactions and a reduced PCR-runtime due to optimized PCR-conditions.

Conclusion: This enables a fast and efficient determination of IL-6 ${ }^{-597 /-572 /-174}$ haplotypes in clinical diagnosis and further evaluation of IL-6 promoter polymorphisms in larger patient cohorts.
\end{abstract}

\section{Findings}

Interleukin-6 (IL-6) is a pleiotropic cytokine with a broad range of effects that is produced by a variety of different cells and plays a crucial role at the interface of adoptive and innate immunity. The increased knowledge about individual genetic susceptibility of the immune system led to the identification of three single biallelic nucleotide polymorphisms (SNP) within the promoter region of the IL-6 gene at positions $-597(\mathrm{G} \rightarrow \mathrm{A})(\mathrm{rs} 1800797),-572(\mathrm{G} \rightarrow \mathrm{C})$ $(\mathrm{rs} 1800796)$ and $-174(\mathrm{G} \rightarrow \mathrm{C})(\mathrm{rs} 1800795)[1,2]$. The three SNPs were shown to be in linkage disequilibrium and naturally occurring IL-6 ${ }^{-597 /-572 /-174}$ haplotypes have been characterized [2].

A number of recent studies investigated the clinical impact of the IL-6 promoter polymorphisms on different major diseases such as chronic obstructive pulmonary disease $[3,4]$, viral infections [5], gout [6], osteoporosis [7], diabetes [8] or allograft survival [9]. Our own group recently presented evidence that the IL- 6 promoter ${ }^{-597 /-572 /-174}$ genotype affects IL-6 secretion [10].

At present, typing of IL-6 ${ }^{-597 /-572 /-174}$ haplotypes requires an elaborate and time-consuming protocol [2]. A twelvereaction PCR-SSP system with eight different allele-specific primers (AS1-AS8) is needed in order to identify both $-597 /-572 /-174$ haplotypes for the three biallelic sites in each individual tested. Since PCR-SSP is DNA-consuming, this procedure requires at least $500 \mathrm{ng}$ genomic DNA; this, however, may be critical with regard to a retrospective analysis, or when valuable samples need to be analyzed. However for subsequent confirmatory investigations of 
larger patient cohorts a rapid and accurate genotyping technique is needed.

Here we report a modified PCR-SSP protocol which is suitable for the genotyping of IL-6 ${ }^{-597 /-572 /-174}$ haplotypes in the Caucasian population. It is faster, less labour-intensive and requires less DNA, since only four instead of twelve PCR reactions are necessary in order to detect all relevant ${ }^{-597 /-572 /-174}$ haplotypes in the Caucasian population (Table 1 ).

For the isolation of genomic DNA from $200 \mu \mathrm{L}$ whole blood, we used the QIAamp ${ }^{\circledR}$ DNA Blood Mini Kit (Qiagen, Hilden, Germany) according to the manufacturer's standard protocol. The DNA concentration was estimated from the absorbance at $260 \mathrm{~nm}$ using a UV- spectrophotometer (GeneQuant pro; Amersham Biosciences, Freiburg, Germany). For validation, DNA samples $(n=100)$ from a previous study [10] genotyped according to the protocol by Terry et al. [2] were used.

Four forward (AS1-F1g, AS2-F3a, AS3-F3g, AS4-F3c) and two reverse primers (AS7-R1C, AS8-R1g) specific for the typing of the AGC (Primermix I), GGC (II), GGG (III) and GCG (IV) IL-6 ${ }^{-597 /-572 /-174}$ haplotype respectively were selected. While primers AS1-F1g, AS7-R1c and AS8R1g have been adopted from the original protocol [2], primers AS2-F3a, AS3-F3g and AS4-F3c have been optimized for uniform PCR-conditions (Table 2).

According to an optimized protocol for PCR-SSP [11] reactions were carried out in a total volume of $10 \mu \mathrm{L}$,

Table I: Interleukin-6 Promoter ${ }^{-597 /-572 /-174}$ Haplotype Frequencies in different caucasian cohorts

\begin{tabular}{|c|c|c|c|c|c|c|c|c|}
\hline \multirow[t]{2}{*}{$\begin{array}{l}\text { Haplotypes major } \\
\text { (minor) }\end{array}$} & \multicolumn{2}{|c|}{$\begin{array}{l}\text { healthy blood donors }(n=100) \\
\text { [Müller-Steinhardt et al. 2006] }\end{array}$} & \multicolumn{2}{|c|}{$\begin{array}{c}\text { healthy controls }(n=182) \\
{[\text { Terry et al. 2000] }}\end{array}$} & \multicolumn{2}{|c|}{$\begin{array}{c}\text { kidney recipients }(n=158) \\
\text { [Müller-Steinhardt et al. 2004] }\end{array}$} & \multicolumn{2}{|c|}{ All $(n=440)$} \\
\hline & number & [\%] & number & [\%] & number & {$[\%]$} & number & [\%] \\
\hline GGG & 113 & 56.5 & 195 & 53.6 & 165 & 52.2 & 473 & 53.8 \\
\hline AGC & 74 & 37.0 & 147 & 40.4 & 135 & 42.7 & 356 & 40.4 \\
\hline GCG & 11 & 5.5 & 19 & 5.2 & 15 & 4.7 & 45 & 5.1 \\
\hline GGC & 2 & I & 2 & 0.6 & I & 0.3 & 5 & 0.6 \\
\hline (AGG) & 0 & 0 & I & 0.3 & 0 & 0 & 1 & 0.1 \\
\hline (ACG) & 0 & 0 & 0 & 0 & 0 & 0 & 0 & 0 \\
\hline$(A C C)$ & 0 & 0 & 0 & 0 & 0 & 0 & 0 & 0 \\
\hline (GCC) & 0 & 0 & 0 & 0 & 0 & 0 & 0 & 0 \\
\hline total & 200 & 100 & 364 & 100 & 316 & 100 & 880 & 100 \\
\hline
\end{tabular}

Table 2: Primer Sequences and Combinations used in PCR-SSP-typing for Interleukin-6 Promoter ${ }^{-597 /-572 /-174}$ Haplotype

\begin{tabular}{|c|c|c|c|c|c|c|c|}
\hline & Primermix & Primer Sequence & $\begin{array}{l}\text { Product } \\
\text { Size [bp] }\end{array}$ & $\begin{array}{l}-597 \\
\text { Genotype }\end{array}$ & $\begin{array}{l}-527 \\
\text { Genotype }\end{array}$ & $\begin{array}{c}-174 \\
\text { Genotype }\end{array}$ & $\begin{array}{c}\text { Detected } \\
\text { major \& (minor) Haplotypes }\end{array}$ \\
\hline I & $\begin{array}{l}\text { AS2-F3a } \\
\text { AS8-RIg }\end{array}$ & $\begin{array}{l}\text { 5'-tgaagtaactgcacgaaatttgagga-3' } \\
\text { 5'-tgcaatgtgacgtcctttagcatg-3' }\end{array}$ & 473 & $A$ & - & $\mathrm{C}$ & $\begin{array}{l}\text { AGC } \\
(\mathrm{ACC})\end{array}$ \\
\hline II & $\begin{array}{l}\text { ASI-FIg } \\
\text { AS8-RIg }\end{array}$ & $\begin{array}{l}\text { 5'-aagtaactgcacgaaatttgaggg--3' } \\
\text { 5'-tgcaatgtgacgtcctttagcatg-3' }\end{array}$ & 471 & G & - & $\mathrm{C}$ & $\begin{array}{l}\text { GGC } \\
(\mathrm{GCC})\end{array}$ \\
\hline III & $\begin{array}{l}\text { AS3-F3g } \\
\text { AS7-RIC }\end{array}$ & $\begin{array}{l}\text { 5'-grtggccaggcagttctacaacagccg-3' } \\
\text { 5'-tgcaatgtgacgtcctttagcatc- } 3^{\prime}\end{array}$ & 449 & - & G & G & $\begin{array}{l}\text { GGG } \\
(\mathrm{AGG})\end{array}$ \\
\hline \multirow[t]{2}{*}{ IV } & $\begin{array}{l}\text { AS4-F3c } \\
\text { AS7-RIc }\end{array}$ & $\begin{array}{l}\text { 5'-grtggccaggcagttctacaacagccc-3' } \\
\text { 5'-tgcaatgtgacgtcctttagcatc-3' }\end{array}$ & 449 & - & C & G & $\begin{array}{l}\text { GCG } \\
(\mathrm{ACG})\end{array}$ \\
\hline & $\begin{array}{l}\beta \text {-globF4 } \\
\beta \text {-globR5 }\end{array}$ & $\begin{array}{l}\text { 5'-gcttaccaagctgtgattcc-3' } \\
\text { 5'-aaggtgcccttgaggttgtc-3' }\end{array}$ & 731 & & & & \\
\hline
\end{tabular}


containing $20 \mathrm{ng}$ DNA, $1 \mu \mathrm{M}$ each of the various allelespecific forward and reverse primers, $0.2 \mu \mathrm{M}$ each of the internal control primers, $10 \mathrm{mM}$ Tris- $\mathrm{HCl}, 50 \mathrm{mM} \mathrm{KCl}$, $1.5 \mathrm{mM} \mathrm{MgCl} 2,0.01 \%$ BSA, 5\% glycerol, $0.1 \mathrm{mg} / \mathrm{mL}$ cresol red, and $0.4 \mathrm{U}$ Taq DNA polymerase.

PCR-SSP was performed with the following cycling program: a 2-min initial denaturation at $95^{\circ} \mathrm{C}$, followed by 10 cycles of $15 \mathrm{~s}$ denaturation at $95^{\circ} \mathrm{C}$ and $1 \mathrm{~min}$ annealing/extension at $65^{\circ} \mathrm{C}$, followed by 20 cycles of $15 \mathrm{~s}$ denaturation at $95^{\circ} \mathrm{C}, 1 \mathrm{~min}$ annealing at $61^{\circ} \mathrm{C}$, and $30 \mathrm{~s}$ extension at $72^{\circ} \mathrm{C}$. Using a PTC-200 cycler (BioRad), the total runtime of the PCR-program was $68 \mathrm{~min}$. The amplification products were separated on $2 \%$ agarose gels containing $0.5 \mathrm{ng} / \mathrm{mL}$ ethidium bromide in a rapid agarose gel electrophoresis (RAGE; ${ }^{\circledR}$ Cascade Biologics, Portland, OR, USA) chamber for $5 \mathrm{~min}$ at $25 \mathrm{~V} / \mathrm{cm}$. The results were obtained by a visual inspection of the gels and documented using a UV documentation device with charge-coupled device (CCD) camera (UVP, Upland, CA, USA).

First-line validation was carried out by genotyping seven reference samples representing all relevant ${ }^{-597 /-572 /-174}$ haplotypes of the Caucasian population (GGG, AGC, GCG, GGC). The genotypes were as follows: AGC/GGG, GGG/ GGG, AGC/AGC, GGG/GCG, AGC/GCG, AGC/GGC and GGG/GGC. Our modified PCR-SSP technique confirmed the typing results of the reference samples in all cases (Figure 1).

Additional validation of the technique could be achieved by retyping 100 healthy blood donor samples previously genotyped according to the protocol by Terry et al. [10]. Our modified technique confirmed all previous typing results unambiguously (data not shown).

PCR-SSP techniques are widely employed for the genotyping of SNPs. After PCR and agarose gel electrophoresis, the genotyping result is evaluated by the presence or absence of an allele-specific PCR product. Moreover, PCR-SSP-typing is suitable for haplotyping of neighbouring SNPs; furthermore, the presence of two alleles on one chromosome can be demonstrated when two appropriate allele-specific primers are combined in a single PCR-reaction. Consequently, complete typing of three neighbouring biallelic SNPs requires twelve PCRreactions! Since this procedure is very extensive and time-consuming it is not suitable for the typing of larger cohorts.

In our study, we describe a modified PCR-SSP protocol which is suitable for rapid IL-6 ${ }^{-597 /-572 /-174}$ haplotyping focusing on the four major ${ }^{-597 /-572 /-174}$ haplotypes (AGC, GGC, GGG, GCG) representing 99.9\% of all haplotypes

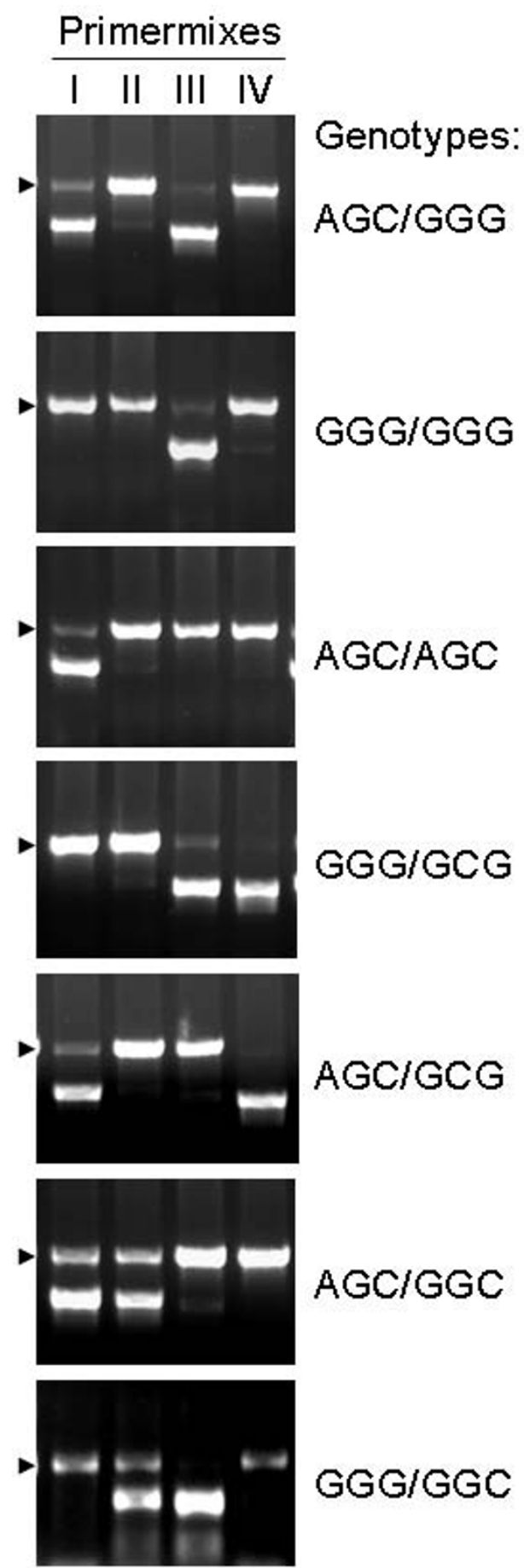

Figure I

Validation of the optimized PCR-SSP protocol by typing of seven reference DNA-samples. Two primers specific for the typing of the AGC (Primermix I), GGC (II), GGG (III) and GCG (IV) IL-6 ${ }^{-597 /-572 /-174}$ haplotype respectively were used. The amplification product (73I bp) of the internal control is marked by an arrowhead. Genotyping results were as expected (AGC/GGG, GGG/GGG, AGC/AGC, GGG/GCG, AGC/GCG, AGC/GGC, GGG/GGC). 
in the Caucasian population (Table 1). Since only four, instead of twelve, PCR-reactions are needed and a protocol with optimized sensitivity is used [11], the amount of required genomic DNA could be reduced from 500 to 100 ng per genotype. This can be extremely valuable, especially if samples of limited quantity have to be analyzed.

Notably, our protocol does not distinguish between the GGG and AGG ${ }^{-597 /-572 /-174}$ haplotype, which has only been detected in one Caucasian individual so far (Table 1). However, as its frequency is extremely low $(0.1 \%)$, this would not affect the overall outcome of association studies. Furthermore, ACC, ACG and GCC also represent minor 597/-572/-174 haplotypes that cannot be distinguished likewise. Even though they have not been observed among Caucasians and are only of theoretical importance, it cannot be ruled out that they might occur in other populations as well.

In order to run all four PCR-reactions under identical conditions, we optimized the selection of the allele-specific primers. Thereby, the runtime of the PCR-procedure could be reduced from 110 to $68 \mathrm{~min}$ with an overall analysis time of approximately 2 hours including all pipetting procedures, DNA-isolation (30 $\mathrm{min})$, electrophoresis (10 $\mathrm{min})$ and documentation (5 $\mathrm{min})$.

In summary, we optimized a previous PCR-SSP protocol for IL-6 ${ }^{-597 /-572 / 174}$ haplo-typing of Caucasian individuals with regard to the number of PCR-reactions, the amount of genomic DNA required and overall runtime. This method represents an important prerequisite for further evaluating the clinical impact of IL- 6 promoter polymorphisms in larger cohorts.

\section{Competing interests}

The authors declare that they have no competing interests.

\section{Authors' contributions}

MMS conceived the study, interpreted results and drafted the manuscript, FS performed SNP-typing and assisted in data analysis, HK participated in study design and provided valuable comments, PB conceived the study, designed the primers and interpreted results. All authors read and approved the final manuscript.

\section{Acknowledgements}

The authors are grateful to Gabriele Rink for perfect technical assistance and to Ms. Daniela Griffiths for carefully editing the manuscript. This study is part of the doctoral thesis work of Friederike Schulte.

\section{References}

I. Fishman D, Faulds G, Jeffery R, Mohamed-Ali V Yudkin IS, Humphries $S$ and Woo P: The effect of novel polymorphisms in the interleukin-6 (IL-6) gene on IL-6 transcription and plasma IL-6 levels, and an association with systemic-onset juvenile chronic arthritis. J Clin Invest 1998, I02:1369-1376.

2. Terry CF, Loukaci $V$ and Green FR: Cooperative influence of genetic polymorphisms on interleukin 6 transcriptional regulation. J Biol Chem 2000, 275: |8|38-|8|44.

3. Cordoba-Lanus E, de-Torres JP, Lopez-Aguilar C, RodriguezPerez MC, Maca-Meyer N, Montejo-de-Garcini A, Aguirre-Jaime A, Perez-Mendez L and Casanova C: Association of IL-6 gene polymorphisms and COPD in a Spanish population. Respir Med 2008, I02:1805-I8II.

4. He JQ, Foreman MG, Shumansky K, Zhang X, Akhabir L, Sin DD, Man SF, Demeo DL, Litonjua AA and Silverman E, et al: Associations of IL6 polymorphisms with lung function decline and COPD. Thorax 2009, 64:698-704.

5. Gadelha SR, Junior Alcantara LC, Costa GC, Acosta AX, Rios D, Kashima S, Covas DT and Galvao-Castro B: Correlation between polymorphisms at interleukin-6 but not at interleukin-10 promoter and the risk of human $T$ lymphotropic virus type I-associated myelopathy/tropical spastic paraparesis in Brazilian individuals. J Med Virol 2008, 80:2I4|-2| 46.

6. Tsai PC, Chen CJ, Lai HM and Chang SJ: Analysis of polymorphisms in the promoter region and protein levels of interleukin-6 gene among gout patients. Clin Exp Rheumatol 2008, 26:84I-847.

7. Magana JJ, Gomez R, Cisneros B, Casas L and Valdes-Flores M: Association of interleukin-6 gene polymorphisms with bone mineral density in Mexican women. Arch Med Res 2008, 39:618-624.

8. Koh SJ, Jang Y, Hyun YJ, Park JY, Song YD, Shin KK, Chae JS, Kim BK, Ordovas JM and Lee JH: Interleukin-6 (IL-6) -572C->G promoter polymorphism is associated with type 2 diabetes risk in Koreans. Clin Endocrinol (Oxf) 2009, 70:238-244.

9. Müller-Steinhardt M, Fricke L, Müller B, Ebel B, Kirchner $\mathrm{H}$ and Härtel C: Cooperative influence of the interleukin-6 promoter polymorphisms -597, -572 and - 174 on long-term kidney allograft survival. Am J Transplant 2004, 4:402-406.

10. Müller-Steinhardt $M$, Ebel $B$ and Härtel $C$ : The impact of interleukin-6 promoter -597/-572/-174genotype on interleukin-6 production after lipopolysaccharide stimulation. Clin Exp Immunol 2007, 147:339-345.

II. Bugert $P$, Lese A, Meckies J, Zieger W, Eichler $\mathrm{H}$ and Klüter $\mathrm{H}$ : Optimized sensitivity of allele-specific PCR for prenatal typing of human platelet alloantigen single nucleotide polymorphisms. Biotechniques 2003, 35: I70-174.

Publish with Bio Med Central and every
scientist can read your work free of charge
"BioMed Central will be the most significant development for
disseminating the results of biomedical research in our lifetime. "
Sir Paul Nurse, Cancer Research UK
Your research papers will be:
• available free of charge to the entire biomedical community
- peer reviewed and published immediately upon acceptance
- cited in PubMed and archived on PubMed Central
- yours - you keep the copyright

